\title{
Occupational sorting of school graduates: the role of economic preferences
}

Citation for published version (APA):

Fouarge, D., Kriechel, B., \& Dohmen, T. J. (2014). Occupational sorting of school graduates: the role of economic preferences. ROA. ROA Research Memoranda No. 009 https://doi.org/10.26481/umaror.2014009

Document status and date:

Published: 01/01/2014

DOI:

10.26481/umaror.2014009

Document Version:

Publisher's PDF, also known as Version of record

\section{Please check the document version of this publication:}

- A submitted manuscript is the version of the article upon submission and before peer-review. There can be important differences between the submitted version and the official published version of record.

People interested in the research are advised to contact the author for the final version of the publication, or visit the DOI to the publisher's website.

- The final author version and the galley proof are versions of the publication after peer review.

- The final published version features the final layout of the paper including the volume, issue and page numbers.

Link to publication

\footnotetext{
General rights rights.

- You may freely distribute the URL identifying the publication in the public portal. please follow below link for the End User Agreement:

www.umlib.nl/taverne-license

Take down policy

If you believe that this document breaches copyright please contact us at:

repository@maastrichtuniversity.nl

providing details and we will investigate your claim.
}

Copyright and moral rights for the publications made accessible in the public portal are retained by the authors and/or other copyright owners and it is a condition of accessing publications that users recognise and abide by the legal requirements associated with these

- Users may download and print one copy of any publication from the public portal for the purpose of private study or research.

- You may not further distribute the material or use it for any profit-making activity or commercial gain

If the publication is distributed under the terms of Article $25 \mathrm{fa}$ of the Dutch Copyright Act, indicated by the "Taverne" license above, 
Maastricht University

Research Centre for Education and the Labour Market | ROA

\section{Occupational sorting of school graduates: The role of economic preferences}

Didier Fouarge

Ben Kriechel

Thomas Dohmen

\section{ROA Research Memorandum}

ROA-RM-2014/9

Research Centre for Education and the Labour Market Maastricht University

P.O. Box 616, 6200 MD Maastricht, The Netherlands

$\mathrm{T}+31433883647 \mathrm{~F}+31433884914$

secretary-roa-sbe@maastrichtuniversity.nl www.roa.nl 


\title{
Occupational sorting of school graduates: The role of economic preferences
}

\author{
Didier Fouarge \\ Ben Kriechel \\ Thomas Dohmen
}

ROA-RM-2014/9*

July 2014

Research Centre for Education and the Labour Market

Maastricht University

P.O. Box 616, 6200 MD Maastricht, The Netherlands

$\mathrm{T}+31433883647 \mathrm{~F}+31433884914$

secretary-roa-sbe@maastrichtuniversity.nl

www.roa.nl

\footnotetext{
* The ROA Research Memorandum Series was created in order to make research results available for discussion, before those results are submitted for publication in journals.
} 


\title{
Abstract \\ Occupational sorting of school graduates: The role of economic preferences**
}

We relate risk attitudes and patience of young graduates from high-school, college and university, measured around the time that they start their labor market career in a large representative survey, to the riskiness and timing of earnings in the occupations they choose to work in. We find a systematic positive and significant relation between willingness to take risks and measures of occupational earnings risks and employment risk that we derive from a large administrative data set. Patient individuals are significantly more likely to choose for occupations with a steep earnings profile. Individuals whose economic preferences are not well aligned with the riskiness and timing of earnings in their initial occupation are more likely to change to an occupation that better matches their economic preferences.

JEL classification: risk preferences; earnings risk; sorting; occupational choice Keywords: J24, J31, D01

\author{
Didier Fouarge \\ Maastricht University \\ ROA \\ P.O. Box 616 \\ NL-6200 MD Maastricht \\ The Netherlands \\ d.fouarge@maastrichtuniversity.nl \\ and GSBE, Netspar \\ Thomas Dohmen \\ Maastricht University \\ ROA and School of Business and Economics \\ P.O. Box 616 \\ NL-6200 MD Maastricht \\ The Netherlands \\ t.dohmen@maastrichtuniversity.nl \\ and GSBE, Netspar, IZA, DIW \\ Ben Kriechel \\ Economix Research \& Consulting \\ Lindwurmstraße 9 \\ D-80337 München \\ Germany \\ ben.kriechel@economix.org \\ and ROA, IZA
}

\footnotetext{
** We thank conference participants from EALE (Pafos, Cyprus) and ESPE (Hangzhou, China), workshop participants at the IZA Workshop on Cognitive and Non-Cognitive Skills (Bonn, Germany) and at LSE Workshop on Non-Cognitive Skills (London, UK), as well as seminar participants at Stockholm University (Sweden), Ruhr-University Bochum (Germany), and Maastricht University (the Netherlands) for their useful comments on previous drafts. Thomas Dohmen acknowledges funding from the Netherlands Organisation for Scientific Research (NWO) for the project "Sorting into incentive systems: how gender and preference heterogeneity affect career choice, earnings, work stress and well-being" (452-10-006).
} 


\section{Introduction}

The choice of an occupation constitutes a major decision in the life of a young adult. It marks the transition from school to work, and heralds an important phase during the life cycle. Choosing the 'right' occupation is not only important from the perspective of an individual; optimal sorting of individuals to occupations is also key because of efficiency considerations, as optimal initial choices avert inefficient costly re-allocation on the labor market. In a utility maximization framework, occupational choice depends on constraints, information, incentives, and preferences. Heterogeneity in economic preferences is therefore expected to affect the pattern of occupational choice. ${ }^{1}$

Occupational choice is intimately connected with educational choice. A particular field of study usually prepares for a subset of occupations. As a result, the intention to enter a certain occupation is expected to already affect the choice of education (Arcidiacono, 2004). In fact, we would predict that individuals choose a schooling career such that their preferences are aligned with the characteristics of the resulting occupational career. Reassuringly, Arcidiacono et al. (2012) show that earnings expectations are considered by students when choosing their field of study. Saks and Shore (2005) - using data from the Panel Study of Income Dynamics and the National Postsecondary Student Aid Survey - and Caner and Okten (2010) - using data from the Turkish Student Selection Exam - provide corroborating evidence. They demonstrate that individuals who are more willing to take risks (as proxied by higher parental wealth) more frequently choose college majors that prepare for occupations with larger earnings variance. ${ }^{2}$

1. It is evident that constraints (e.g. available economic resources, capabilities, competencies, personality traits), information, and preferences for other characteristics of occupations beyond those that we consider, affect occupational choice. As a result we expect heterogeneity in risk and time preferences to only partially explain heterogeneity in occupational choice.

2. It is obvious that the riskiness of future occupations is only one factor in the assessment of the riskiness of an education choice. Types and levels of education differ, for example, in terms of failure risk. De Paola and Gioia (2012) investigate how risk attitudes affect the choice of majors among students of Italian universities and find that more risk adverse students are more likely to choose fields that have lower drop-out rates. These pre-labor market sources of riskiness are not necessarily aligned with the riskiness of occupations. It could, for instance, be the case that rather low-risk types of education qualify predominately for occupations that are characterized by large earnings and unemployment risk. As a result, it is not clear a priori whether the correlation between risk preferences and riskiness of an occupation is reinforced or attenuated by preceding education choices. 
In this paper, we take a somewhat different perspective. We do not focus on how occupation characteristics affect the choice of education, but analyze the relationship between individuals' risk attitudes and occupation-specific earnings risk, as well as the relationship between individuals' patience and the slope of the earnings profile of the occupation they choose at the time when they have completed their education. The rationale behind our approach is the idea that the correlation between risk preferences (time preferences) and riskiness (wage profile) of an occupation is not entirely reflected by the correlation between risk preference (time preference) and type of education. This is because a specific field of study or type of education qualifies an individual to enter various occupations, which partly explains the large variance in earnings within a field of education (Weiss, 1970; Stark, 2007; Brunello \& Cappellari, 2008). The sets of occupations that can be entered with a given educational background overlap, such that workers with different educational careers can enter the same occupation. In the Netherlands, the set of occupations individuals with a specific educational background can choose from is large in general (Heijke et al., 2003).

If economic preferences matter for occupational choice, individuals who are risk averse are expected to abstain from entering risky occupations. In fact, some studies have documented that the risk attitudes of workers are related to characteristics of the occupations they work in, such as fatality risk (DeLeire and Levy, 2004) or earnings risk (Bonin et al., 2007). Likewise, patient individuals should be attracted by occupations with steep earnings profiles and deferred compensation (Heckman et al., 2006). Previous studies typically document correlational evidence on the link between job attributes and workers' preferences, where preferences are often proxied by other variables such as wealth (for risk preferences) or smoking behavior (for time preference). A causal interpretation of these correlations requires that preferences are not entirely determined by systematic differences in occupational characteristics. Even though empirical evidence suggests that risk preferences are rather stable and change only gradually over the life-cycle, ${ }^{3}$ skeptics have raised the concern that individuals observed in these studies have been potentially exposed for a long time to the attributes of the occupations they work in, such that their preferences have been shaped by the characteristics of the occupations. It is

3. Sahm (2012) shows that risk preference does change with age but reports significant rank correlation in the repeated measurement of risk preference. About three quarter of the variation in risk preference over time is explained by persistent differences in individual's risk preference. Meier and Sprenger (2010) show that the intertemporal correlation of time preference at the individual level is high, and that changes in time preference are unrelated to socio-demographic characteristics, labor market status, family composition or changes in income. In their study among children and adolescents aged 10 to 18 years old, Sutter et al. (2013) find that there is hardly any age variation in risk preference and patience. 
therefore important to assess whether the same pattern of correlations also holds for graduates from high-school, college and university who have just completed a study and who have not been exposed to the characteristics of their occupation for a long time.

In this paper, we therefore measure risk attitudes and patience directly among young individuals around the time that they make their occupational choice, and relate these preference measures to occupation attributes, such as earnings risk, employment risk and earnings growth paths. We rely on validated survey questions and scales that we introduced into a large survey of graduates in the Netherlands, the ROA School Leavers Survey. We first confirm the finding by Bonin et al. (2007) concerning the relation between risk attitudes and occupation-specific earnings risk. We measure, following McGoldrick (1995), this earnings risk by the occupation-specific standard deviation of the residuals from a Mincer earnings regression, using a large administrative earnings data from Statistics Netherlands (CBS). We deliberately use a different data source than our graduates survey to construct our measures of occupational characteristics because early career earnings are not likely to adequately capture the differences in lifetime occupational earnings risks and earnings profiles. ${ }^{4}$ Moreover, individuals are likely to make choices based on information that is sampled from the distribution of earnings of the entire working population.

We extend upon previous studies discussed in Section 2 by including more detailed aspects of the wage risks by separating out employment risk and the mid-career earnings risk as a result of differential wage profiles - resulting from individuals' career choices - that could be occupation specific. We show that young entrants who are more willing to take risks are also significantly more likely to choose for occupations with a high mid-career earnings risk, and a high employment risk (as reflected by a high level of cyclical sensitivity, and a high risk of unemployment). Young entrants who are patient are more likely to sort into occupations with a steep earnings profile. We demonstrate the robustness of our findings to a number of alternative model specifications. In particular, we show that our findings are robust to controlling for field of study choice and graduates' ability, and to controlling for job characteristics and job disamenities that would otherwise invalidate our measure of earnings risk. ${ }^{5}$

4. Bonin et al. (2007) construct their earnings risk measures based on wage information on the same sample of individuals whose risk attitudes are later related to the occupation they work in. Isphording (2010) and Pollmann et al. (2012) replicate the Bonin et al. (2007) study using earnings data from administrative files.

5. As discussed in Section 5.3, such job characteristics could result in compensating wage differences within occupations that affect occupation-specific variations in earnings, but are unrelated to the earnings risk of occupations. 
Additional support for the hypothesis that occupational choice is affected by risk and time preferences derives from the finding that individuals whose preferences are not well aligned with the earnings risk and earnings profiles of their initially chosen occupation are more likely to switch towards an occupation that better matches their economic preferences.

This paper is organized as follows. In Section 2, we develop our conceptual framework and empirical strategy. We describe the data in Section 3, and present our main findings in Section 4. We then discuss robustness checks in Section 5 and investigate in Section 6 whether the quality of the alignment of economic preferences and characteristics of the occupation affects job mobility. Section 7 concludes.

\section{Conceptual framework and empirical strategy}

We build on the notion that occupations differ with respect to a range of characteristics including their riskiness and the steepness of the wage profile. Some occupations offer relatively high entry wages, but rather flat age-earnings profiles, while other occupations offer relatively low entry wages but high deferred payments, thereby generating steep age-earnings profiles. Likewise, occupations differ with respect to the variance of earnings. Information on the earnings profile of occupations and variance of earnings is available to young individuals in the Netherlands at rather negligible costs, so that we expect that they use this information when choosing which occupation to enter. For simplicity, and analogous to previous studies on occupational choice, we assume that riskiness and steepness of the wage profile are separable from other factors that affect occupational choice. We further acknowledge that individuals differ with respect to their risk preferences and time preferences. In our empirical analysis we calculate the earnings risk, employment risk and steepness of earnings profiles by occupation, and relate these occupational characteristics to the risk attitudes and patience of young graduates who recently entered in these occupations, using a regression framework, in which we also control for other factors that might affect occupational choice.

It is apparent that patient workers are expected to be more likely to sort into occupations with steep earnings profiles and deferred compensation (Heckman et al., 2006). ${ }^{6}$ Munasinghe and Sicherman

6. Some studies have also related risk attitudes to wage growth, with mixed results. E.g., Shaw (1996) uses data from the US Survey of Consumer Finances to show that individuals who are more willing to take risks experience higher wage growth. However, Brudia et al. (2012) replicated her study using the same data as 
(2006) suggest such a link empirically. Using smoking as a proxy for impatience, they find that smokers in the National Longitudinal Survey of Youth have flatter wage profiles. ${ }^{7}$ In order to illustrate how sorting into occupations based on risk preferences works, consider the following simplified framework in which workers sort into occupations based on risk preferences. Suppose that occupations can be ranked according to riskiness and that workers can be ranked according to their risk preferences. For simplicity, assume that a fixed number of $n$ workers, who only differ with respect to their risk preference, can work in each occupation. Since risk averse workers prefer the least risky occupation ceteris paribus, they command a compensation for working in riskier occupations. The theory of compensating wage differentials predicts that a reward is offered for working in a risky occupation. If employers cannot observe workers' risk preferences, this reward will be the same for all workers in a given occupation. This premium makes the last worker (i.e. the $n$th worker) who is attracted into the occupation indifferent to working in the next less risky occupation (see also Hartog, 2011). Sorting into occupations based on risk preferences will then result because the workers who are more willing to bear risk than the $n$th worker will opt for the riskier occupations and collect the premium that more than compensates them for the risk.

Using US Census data, King (1974) was probably the first to provide empirical evidence that expected earnings are higher in occupations that entail higher earnings risks. King (1974) also showed that individuals who are more willing to take risks (as proxied by higher parental wealth) work in riskier occupations. Bonin et al. (2007) find corroborating evidence in their analysis of data from the German Socio-Economic Panel Study (SOEP). They document the existence of a wage premium in occupations with higher earnings risk, and report a positive correlation between earnings variance in occupations and the risk attitudes of individuals who have been working in these occupations. See also Guiso and Paiella (2005) for related evidence using the Italian Survey of Household Income and Wealth. Evidence for a correlation between risk attitudes and other risky facets of occupations, such as fatality risk, has also been provided (e.g., DeLeire and Levy, 2004). ${ }^{8}$

well as the German Socio-Economic Panel, the Spanish Survey of Household Finances, and the Italian Survey of Household Income and Wealth but did not find that risk attitude is connected with the wage growth.

7. Antecol and Cobb-Clark (2010) find that willingness to work hard, impulsivity, and the tendency to avoid problems of young respondents (aged 18-28) to the US National Longitudinal Study of Adolescent Health are related to sorting into occupations that are characterized by a larger share of male workers and higher average wages. Their measure of impulsivity is related to time preferences but arguably captures present-bias rather than patience (Vischer et al., 2012).

8. Studies also provide evidence for a positive relation between willingness to take risks and the decision to become self-employed (e.g., Caliendo et al., 2010; Cramer et al., 2002; Ekelund et al., 2005). 
In this paper we study how graduates' risk attitudes relate to their choice of occupation. In contrast to most other studies, we measure preferences directly rather than use proxies such as smoking behavior or parental wealth. We characterize the riskiness of occupations by the cross-sectional earnings risk and the employment risk. As argued by King (1974), these are two key dimensions to occupational income uncertainty. Employment risk determines the expected length of employment spells and hence contributes to the variance of life-time earnings. Among those who are working, the cross-sectional variation in earnings within an occupation partly reflects the distribution of quality of job matches, and partly the distribution of shocks. Both are sources of the earnings risk an individual faces. This is particularly evident from the point of view of a labor market entrant who has no prior information about the draw from the job match quality distribution. But even if pre-labor market human capital or ability contain some information about the likelihood of ending up in particular ranges of the wage distribution in an occupation, individuals cannot predict their earnings perfectly based on human capital characteristics, even after controlling for ability (Weiss, 1970; Arcidiacono, 2004) and educational choice. In a robustness check, we abandon the assumption that individuals have absolutely no idea about the range of the wage distribution they will end up in, and control for young graduates' abilities.

We assume that individuals who enter the labor market can observe wages of workers in the economy. They can thus infer the variances of the cross-sectional earnings distributions within occupations (just like the econometrician does), and take these as proxies for the occupational earnings risk. There is in fact evidence that students are able to make good earnings prediction when they make their schooling and occupational choice decision (Webbink \& Hartog, 2004), and that students know more about the distribution of earnings at the end of the schooling career than in their first year of study (Betts, 1996). Students have also been shown to anticipate wage distributions, and to expect compensation for wage risk (Schweri et al., 2011). In the Netherlands, wage information is provided with the intention to facilitate occupational choice of young individuals. For example, the Ministry of Education, Culture and Science finances an internet platform to assist the choice of education and occupation, which provides wage information (e.g., www.studiekeuze123.nl). Independent commercial platforms that provide such information also exist (e.g., www.keuzegids.org). Dutch magazines such as Intermediair and Elsevier publish (in print and on their website) wage information by occupation on a regular basis, including average, median and maximum wage, as well as wage growth in the recent past and wage prospects by tenure length. Hence, we can safely assume that young individuals have access to information on wage and employment prospects to help them make their study and occupational choice. 
One might raise the issue that educational choice and occupational choice are intertwined. However, the existence of the information platforms that target students and labor market entrants already indicates that occupational characteristics affect the choice of education that prepares for the preferred occupation. This already preempts the potential criticism that educational choice completely determines the choice of occupation while occupational characteristics play no role at all. There are additional objections against the concern that the riskiness of occupations plays no role once education is completed. As we already explained in the introduction, the set of occupations individuals who have completed education in a specific field can choose from is relatively large (Heijke et al., 2003). Moreover, the variance in earnings within field of education is large (Brunello \& Cappellari, 2008). We will report corroborating evidence from a robustness check, in which we condition on the completed field of study, and show that risk attitudes are significantly related to the occupation choice.

In our empirical analysis, we construct two measures of occupational risk, which we explain in greater detail below (Section 3). First, following McGoldrick (1995) we construct a measure of occupation specific earnings risks as the standard deviation of the residuals from a Mincer earnings regression in an occupation. In our estimation, we rely on administrative earnings data from a large representative sample of the Dutch population. Our regression to calculate the occupational earnings risk includes occupation fixed-effects so that our earnings risk measure reflects unsystematic variations in earnings that are unrelated to compensating wage differentials across occupations. We also construct a measure of mid-career earnings risk that follows the same approach but is based on estimates from the subsample of workers aged 40-49. Second, we use two measures of occupation-specific employment risk, acknowledging that occupations differ with respect to the sensitivity to business cycles as well as with respect to unemployment risk in general. The first measure reflects the changes in employment levels of an occupation across the economic cycle, and is as such a broad measure of cyclicality, whereas the second one is the more narrowly defined unemployment risk for a given occupation. We conjecture that young labor market entrants with low willingness to take risks sort into occupations which are less risky in terms of earnings risk, mid-career earnings risk, cyclical sensitivity, and unemployment risk.

Previous studies (e.g., Bonin et al., 2007) have found a relation between earnings risk and risk attitudes, but arguably do not shed light on the causal nature of this relationship. First, the wage structure might be endogenous. Principal-agent theory, for example, implies that the optimal incentive contract entails more variable pay the more willing agents are to take risks. Hence, wages might become more variable 
in occupations that employ less risk averse workers. Second, if risk attitudes are malleable and shaped by experience and exposure, those who have been working in risky occupations might become more willing to take risks. In our analysis of recent graduates, we can basically rule out that the first mechanism of endogenous wage structures drives the correlation between earnings risk and risk preferences. In addition, exposure effects could definitely be ruled out if we observed workers before they start working in their chosen occupation. However, we only elicit the risk attitudes of school leavers and graduates shortly after they have entered the labor market. Yet, our results are clearly meaningful if risk preferences were either completely stable or changed only slowly over time.

While evidence on the stability of risk preferences is still rather scarce, it clearly indicates that risk preferences are rather stable and change only very gradually over the life course, but that risk attitudes are measured with error. For example, the correlation between answers to the general risk question in the German Socio-Economic Panel Study, i.e., the same risk measure that we use in our analysis, over a horizon of eight years (2004-2012) is 0.46 . This correlation although clearly below 1 , indicates a high degree of stability, because measurement error drives the correlation down. Dohmen et al. (2010) showed, for example, that the test-retest correlation for this risk measure, i.e. the correlation between responses to the same question in interviews that are 2 to 6 weeks apart, is 0.62 and 0.6 in two independent samples. This correlation remains even when controlling for the few important life events that might be expected to change risk attitudes, such as death of partner or job loss. This is an important finding as it refutes the concern that labor market entry per se, which might be regarded as a major life event, could potentially affect young individuals' preferences. Beauchamp et al. (2011) found a testretest correlation for the same measure of 0.62 within a sample of Swedes. These consistent findings of a correlation in answers of about 0.6 over very short intervals, during which the underlying preference parameter arguably remains constant, suggest that measurement error drives the correlation down from 1 to 0.6 , even if risk preferences do not change. Judged against this benchmark, a correlation that remains stable around 0.5 after 1 to 8 years implies that risk attitudes change only slowly over longer time horizons. This evidence is consistent with the findings by Sahm (2012), who, uses data from the 1992-2002 waves of the Health and Retirement Study and finds that persistent heterogeneity in risk attitudes accounts for roughly 70 percent of the variation in risk attitudes. She documents a modest decline in willingness to take risk with age for cohorts born between 1931-1947. 
Given the evidence on the relative stability and only gradual malleability of risk preferences, our focus on graduates around the time they make their occupational choice has the advantage that we can dismiss the conjecture that a strong correlation between risk attitudes and the riskiness of occupations is driven by exposure effects. It also makes us confident that the relation between patience and the steepness of earnings profiles is not the result of a process of endogenous preference formation.

\section{Data and measurement}

\subsection{Occupation and economic preferences of graduates}

We measure economic preferences of respondents to the ROA School Leavers Survey, a nationally representative survey of graduates in all fields and at all levels of education in the Netherlands. The graduates in our survey thus either have just obtained a university, college or high-school degree, or a diploma at a lower level of education. They can then either enroll in subsequent education (usually at a higher level) or enter the labor market. Respondents were first interviewed by way of a postal survey in autumn 2008, one and a half years after having left school. The survey includes information on schooling choices and programs, and current activity. In total almost 40,000 graduates participated in the survey. At the time of the survey, about $60 \%$ of all graduates have enrolled in a subsequent study and about $40 \%$ have entered the labor market. For those who have entered the labor market, information on the current occupation is gathered. We use a classification of occupations that reflects both the level and the field of occupation, and categorize 44 occupations at a level of aggregation comparable to the ISCO 2 digit classification. One year later, in autumn 2009, we conducted a web-based follow-up survey. That survey contained a large battery of questions on non-cognitive skills, among which risk attitude and time preference. About 6,700 individuals participated in the follow-up survey. ${ }^{9}$ We restrict the analysis to graduates who are 35 years old or younger, who have a paid job, and who obtained their degree through the regular track. ${ }^{10}$ This leaves us with 4,584 young individuals. Their age depends on the educational track they followed. On average, they are 23 years old. Sample statistics are reported in Table A.1 in Appendix A.

9. About 20,000 individuals indicated they would be willing to participate in a follow-up survey and provided their e-mail address. The probability of taking part in this web-survey is unrelated to the graduates' risk attitude and the earnings risk of the occupation in which they work.

10. We exclude individuals who obtained their degree through a dual track or part-time study because they combine study with paid employment and have therefore been exposed to characteristics of a particular occupation during their study. 
Risk preference is measured in the follow-up survey using a survey question in which graduates have to rate how willing they are to take risks in general on a scale from 0 ('not at all willing to take risks') to 10 ('very willing to take risks'). This self-reported risk attitude has been shown to correlate significantly with risk-taking in lottery choice experiments (Dohmen et al., 2011), as well as with survey respondents' willingness to choose for a lottery voucher with unsecure outcome rather than a voucher with a safe pay-off as compensation for their participation in a survey (Fouarge et al., 2012). Because stated risk attitudes might capture domain-specific aspects (see Weber, 2001), we also use a domain-specific version of this question that asks how people would rate their willingness to take risks when it comes to their career. ${ }^{11}$ Our results are based on this career risk question, but we show that they also hold when we use the general risk question. ${ }^{12}$

We measure graduates' patience using one question from the validated Consideration of Future Consequences Scale from Strathman et al. (1994). This scale has previously been used by Borghans and Golsteyn (2006) and Webley and Nyhus (2006) to measure time discounting. Although the original scale has 12 items, we included the item that best captures the intertemporal trade-off (highest factor load in the scale) in our graduate's survey. In a range from 1 ('disagree completely') to 7 ('agree completely') our respondents could report to what extent they agree with the following statement: "I often work on things that will only pay off in a couple of years". ${ }^{13}$

Our data also include a quantitative question to elicit people's discount rate. The wording of the question is: "Imagine you are offered an amount of money. You can choose to receive the money now or after exactly one year. If you want the money now, you would receive $€ 1,000$. How many euro's would you need in order to choose to receive the money in one year time only? $€$... in one year time rather than $€ 1,000$ now." However, it seems that a substantial fraction of the respondents had difficulties with the question (see also Peters et al., 2006): 620 graduates have implied annual discount

11. Dohmen et al. (2011) show that the domain-specific risk questions are the best predictors of behavior in the specific domains, but that only the general risk question predicts behavior in all domains.

12. As the 2008 main survey included the question on the willingness to take risks for a subsample of the graduates, we have two measures of risk preference. We find that the correlation between the willingness to take risk in the 2008 and 2009 survey is high (0.57) and significant, which is in line with findings from Beauchamp et al. (2011) and Dohmen et al. (2010). The intertemporal correlation in risk attitude among graduates who are still in education, and whom we excluded from our analyses, is not statistically different from that in our estimation sample.

13. The correlation between patience and general risk attitude is 0.036 and significant at the $5 \%$ level. The correlation between patience and career risk attitude is 0.052 and significant at the $1 \%$ level. 
rates that are negative or exceed $250 \% .{ }^{14}$ For this reason, we prefer the survey measure of patience rather than the annual discount rate that is implied by the answer to the quantitative survey question. Excluding these graduates with negative or excessive implied annual discount rates, we find that the correlation between the patience measure and the implied discount rate is negative $(-.044)$, and significant at the $1 \%$ level: people who are more patient have a higher discount rate. Using the measure of the annual discount rate instead of patience does not seem to affect our results.

\subsection{Occupational earnings risk}

Following McGoldrick (1995), we measure the occupational earnings risk as the variation in the occupational specific residuals from a Mincer earnings regression. However, unlike Bonin et al. (2007), we do not derive the occupational earnings risk from the set of individuals for which we measure the economic preferences since using the contemporaneous earnings information of graduates would lead to obvious issues of endogeneity, and selection into the labor market since graduates, depending on their educational level, might face different choice sets (we deal with this in Section 5.2). Rather, we base our estimation of the earnings regression on a representative sample of the Dutch working population: we use the Dutch administrative earnings data from Statistics Netherlands matched at the individual level to the Dutch Labor Force Survey. ${ }^{15}$ The data contain representative wage earnings information of 172,000 individuals aged 20 to 59 and cover the period 2001-2007. Young graduates in our survey arguably sampled the earnings information from the same underlying distribution during the period in which they shaped their wage expectations and thought about their occupational choice.

We regress the log hourly earnings on gender, age, age squared, year dummies, 27 educational dummies that reflect combined level and field of study ${ }^{16}$, and 44 occupational dummies. Our first measure of the occupational earnings risk is the occupation-specific standard deviation of the residuals from this earnings regression. This measure reflects the extent of earnings uncertainty over the

14. Note that the implied rate of return an individual requires to wait for one year to receive the delayed payoff rather than the immediate payoff only equals the discount rate under additional strong assumptions, such as the linearity of the utility function and a set of other assumptions that have to be made to arrive at the discounted utility model (see Frederick et al., 2002).

15. This is necessary as the administrative data do not include information on occupation or education level and field. We exclude individuals who are self-employed, have a wage lower than the minimum wage, or have been employed for less than three months.

16. This allows us to control for the education-occupation match. 
complete earnings distribution within occupations. ${ }^{17}$ As found in previous studies for the US (King, 1974; Murphy \& Topel, 1987) and Europe (Hartog et al., 2003) ${ }^{18}$ the earnings risk correlates positively with the log hourly earnings (the correlation in our data equals 0.267 and significant at a $10 \%$-level) suggesting individuals working in more risky occupations require compensation in terms of a higher wage.

As the above measure of earning risk comprises all wage information across the entire career of workers who currently work in a particular occupation, the measure also reflects heterogeneity in occupationspecific life-time earnings profiles. An arguably cleaner measure of the earnings risk of an occupation is the earnings risk at mid-career. This is calculated as the occupation-specific standard deviation of the residuals from the above regression, but for individuals in the age group 40-49. The occupation specific standard deviation of the residuals at age 40-49 measures differences at a later stage in the career. In essence it charts the development of wages in an occupation, which is related to the steepness of the wage growth and the accumulated earnings risk in an occupation. It is related to the increasing difference with age between high and low wages within occupations. Both earnings risk measures are matched to the ROA School Leavers Survey using the occupational code. Young individuals with low risk attitude are expected to sort into occupations with low earnings risk and low mid-career earnings risk.

\subsection{Occupational employment risk}

Occupations also differ with respect to the sensitivity to business cycles and unemployment risk in general. We have two measures of such an occupation-specific employment risk. The first one captures the changes in employment levels of an occupation across the economic cycle, and is as such a broad measure of cyclicality, whereas the other one is the more narrowly defined unemployment risk for a given occupation.

The cyclical sensitivity of occupations measures the extent to which employment within each occupation fluctuates over the business cycle. It accounts for the extent to which employment in specific occupations varies with changes in employment at sector level over the years (Appendix B). This

17. As an alternative measure of the earnings risk we used the estimated interquartile range: a larger estimated interquartile range for a particular occupation would reflect the high earnings risk of that occupation. The method has the advantage that the effect of covariates can vary at different points of the earnings distribution. We replicated our findings using this measure and found qualitatively similar results to those presented here.

18. See Hartog (2011) for a review of this literature. 
indicator captures occupation-specific uncertainties in employment probabilities and its resulting effect on expected earnings, but, more importantly, it reflects a psychological component of the occupational specific risk: that of not being able to find employment in one's occupation. This indicator is calculated for 44 occupations using the Dutch Labor Force Survey for the years 1987-2008. The data consist of more than 300,000 individuals aged $15-64$. The indicator for cyclical sensitivity is matched to the ROA School Leavers Survey by the occupational code. The correlation between an occupation's cyclical sensitivity and the earnings risk is 0.273 and significant at the $10 \%$-level. Young individuals with low risk attitude are expected to sort into occupations with low cyclical sensitivity.

We complement this measure of cyclical sensitivity with a measure of unemployment risk, i.e., a measure of the occupation-specific probability of experiencing unemployment. It is calculated as the predicted probability of experiencing a transition from employment to unemployment using a Probit model that controls for gender, age, age squared, education dummies, year dummies, and occupational dummies. This predicted probability is calculated for our 44 occupations using the Dutch Labor Supply Panel, the longest representative panel dataset in the Netherlands. With this biennial panel, we observe individuals' transitions from employment to unemployment between two years. Although the panel started in 1985, information on occupation is only available as from 1994. We use the 1994-2008 waves of data for our computations, with about 11,200 persons in the age group 20-59. ${ }^{19}$ The predicted unemployment risk is matched to the ROA School Leavers Survey by the occupational code. This indicator reflects the monetary but also the psychological costs associated with unemployment. The correlation between unemployment risk and the earnings risk is not statistically significant. ${ }^{20}$ Young individuals with low risk attitude are expected to sort into occupations with low unemployment risks.

\subsection{Occupational earnings growth}

To capture the steepness of the age-earnings profile, we construct an earnings growth measure. We calculate the earnings growth for each occupation as the difference in mean log earnings for the age group 40-49 and the age group 20-29. We do this using the same data as is used to calculate the

19. We have about 25,000 persons-year observations. Note that we also use the 2006 and 2008 waves of the Dutch Labor Supply Panel in Sections 4 and 5.

20. There are at least two reasons for the lack of significant correlation between the two risks. Firstly, the unemployment risk is estimated from a smaller sample, and thus, possibly, with less precision. Secondly, the earnings risk is estimated solely on a sample of employed individuals, and therefore - contrary to other studies (e.g. Murphy \& Topel, 1987) - does not include the earnings risk that follows from losing employment. 
occupational earnings risk. Young individuals who are patient are expected to sort into occupations with steep earnings profiles.

\section{Results}

\subsection{Risk attitude and earnings risk}

Figure 1 graphically shows the relationship between risk attitudes and the riskiness of occupations. The different charts show positive relationships between the average risk attitudes of graduates who opted for a particular occupation (depicted on the horizontal axis) and our measures of earnings risk (Chart A), mid-term earnings risk (Chart B), cyclicality (Chart C), and unemployment risk (Chart D). Each occupation is represented by a circle, the surface of which reflects the size of the occupation. ${ }^{21}$ The solid line shows the prediction of linear regression of the respective earnings measure on risk attitudes of graduates working in the occupation (i.e., the regression line is weighted by the size of the occupation).

Chart A shows a positive relationship between our measure of occupational earnings risk, which is based on the distribution of wages among 20 to 59 years-old workers, and career risk attitudes of graduates. We also found this relationship when we consider the general risk question (Figure C.2 in Appendix C). This earnings risk measure can be interpreted as the perceived earnings risk if graduates sample information on earnings over the whole distribution of earnings. The earnings risk of an occupation around mid-age, when careers outcomes have manifested themselves, is depicted in Chart B, in which the earnings risk of 40-49 year olds is used, rather than that for the whole age population within an occupation. Both charts show a significant and positive relation suggesting that graduates who are more willing to take risks in their career indeed sort into occupations that are associated with a large earnings risk. $^{22}$

21. All positive relationships documented in the figure are robust to the exclusion of small occupations with less than 30 observations. In total 14 occupations have fewer than 30 observations.

22. Figure $C .1$ in Appendix $C$ relates career risk attitude to the average wage within each occupation. Similar to Bonin et al. (2007), the figure shows a positive relationship (see also Le et al., 2010). The correlation between the average wage and our measure of earnings risk is positive (0.313) and significant at the $1 \%$-level. 
Figure 1: Career risk attitude of graduates and occupational risks ${ }^{\text {a) }}$

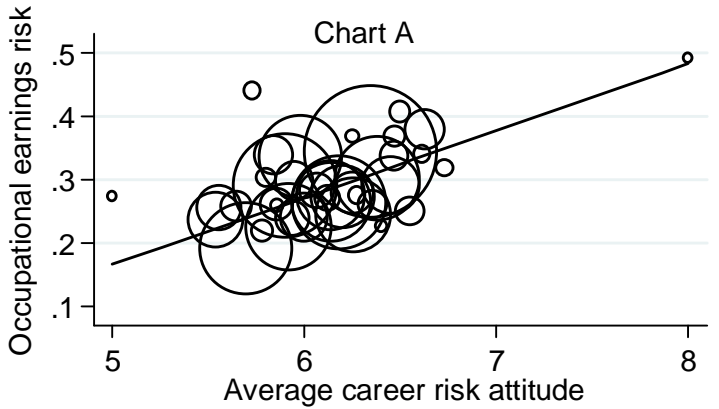

○ Observed W Weighted linear fit

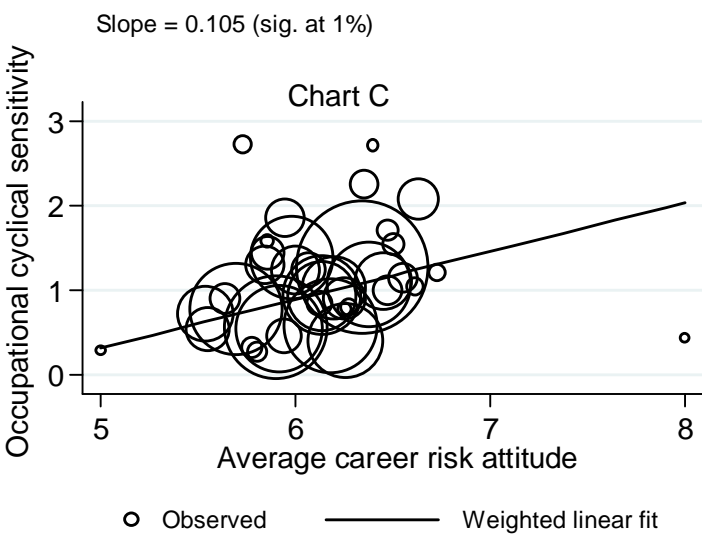

Slope $=0.570($ sig. at $1 \%)$

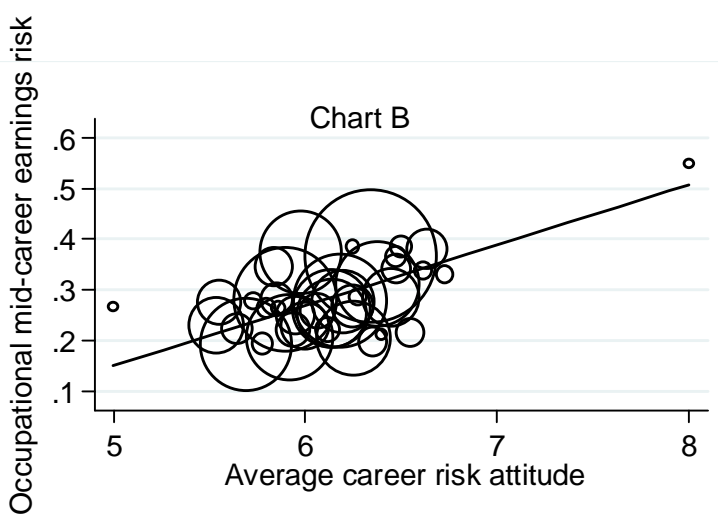

- Observed

Weighted linear fit

Slope $=0.119($ sig. at $1 \%)$

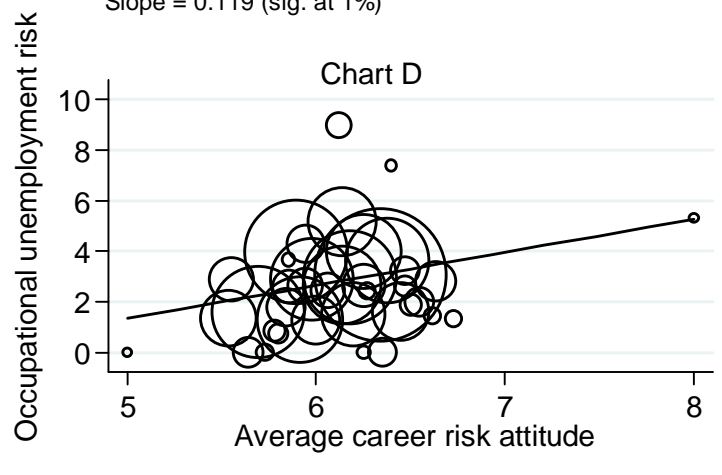

- Observed

Weighted linear fit

Slope $=1.301($ sig. at $1 \%)$

a) Chart A: earnings risk; Chart B: mid-career earnings risk; Chart C: cyclical sensitivity; Chart D: unemployment risk.

Examples of occupations with low earnings risk are "teachers" and "higher medical and paramedical occupations". Graduates in such occupations tend to have a lower career risk attitude. Examples of occupations with a high earnings risk are "managers" and "scientific medical and paramedical occupations" ${ }^{23}$ Graduates in such occupations tend to have higher risk attitudes.

\subsection{Risk attitude and employment risk}

Chart $C$ in Figure 1 illustrates the correlation between career risk attitude and occupational cyclical sensitivity. In occupations with higher cyclical sensitivity, employment tends to fluctuate more with changes in the economic cycle. They are thus an indicator of risk (and opportunities) depending on the

23. Higher level (para)medical occupations include, e.g., specialized nurses (intensive care, pediatric, radiology) and paramedics. Scientific (para)medical occupations are mainly medical doctors in its various specializations. 
labor market development. On average, graduates with high willingness to take risks sort into occupations with higher cyclical sensitivity. Examples of such occupations are "higher agricultural occupations" and "scientific medical and paramedical occupations".

Likewise, Chart D shows that graduates with high willingness to take risks sort into occupations with higher risks of unemployment. Examples of occupations with a high risk of unemployment are "elementary occupations" (such as lower level and unskilled production, transport, or agricultural workers) and "lower level service occupations" (such as unskilled catering workers, or unskilled care workers).

\subsection{Patience and earnings growth}

Occupational sorting on time preference is illustrated in Figure 2. The variables of interest are our measure for patience and the occupation specific earnings growth. The figure shows a positive relationship between both variables: individuals who are patient choose occupations with high earnings growth, while those who are impatient opt for occupations with limited earnings growth prospects. ${ }^{24}$ Examples of occupations with low growth profiles are "elementary occupations" and "lower level care occupations". Graduates in such occupations tend to be more impatient. Examples of occupations with a high earnings growth profile are "scientific medical and paramedical occupations" and "science and engineering". As illustrated in Figure C.3 in Appendix C, the relation between implied annual discount rates and occupational earnings growth rates is negative and significant, which confirms the finding in Figure 2.

24. The relation in Figure 2 is robust to the exclusion of occupations with fewer than 30 observations. 
Figure 2: Patience of graduates and occupational earnings growth

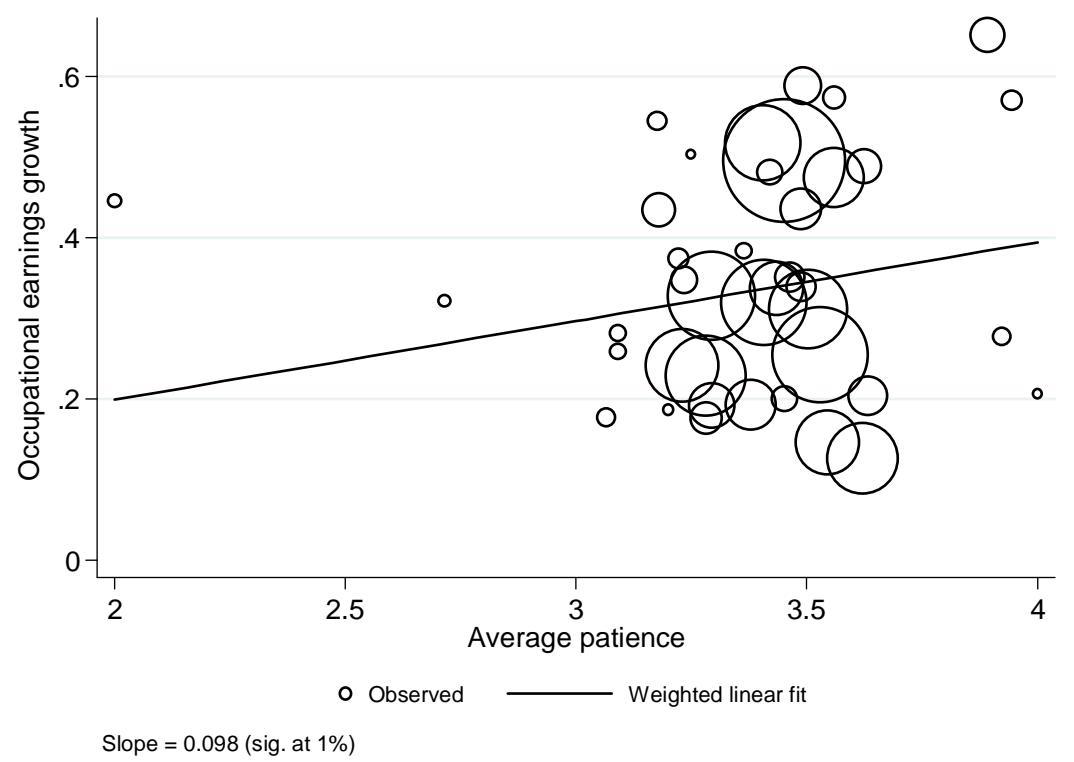

\subsection{Estimation results}

In Table 1, we regress characteristics of occupations on economic preferences of the graduates in our survey. We standardized both the dependent and the independent variables and report the standardized regression coefficients. The top panel does not include any control variables while the bottom panel includes controls for age, gender, migration background, education leve ${ }^{25}$, Body Mass Index (BMI), and measures of the Big Five (openness to experience, conscientiousness, extraversion, agreeableness, and neuroticism). ${ }^{26}$

25. We distinguish among the following levels of education and educational tracks: ISCED 2 or less, ISCED 3 vocational school-based track, ISCED 3 vocational practical-based track, ISCED 3 non-vocational track, ISCED 5B and ISCED 5A. The education level is potentially endogeneous if graduates, on the base of their preferences, first choose their level of education and only then an occupation. Excluding the education level from the set of regressors does not yield statistically significant different estimates for career risk attitude and patience.

26. Research shows that BMI matters for the wage as well as the educational and occupational choice (Han et al., 2011). The Big Five is measured using 15 questions from the German Socio-economic Panel Study that we translated into Dutch and included in our graduates' survey. Gerlitz and Schupp (2005) provide details on the construction and validity of this short Big Five scale. Controlling for personality could matter as Borghans et al. (2008) show that risk attitude is correlated to facets of personality. Almlund et al. (2011) also show that personality is related to a range of economic outcomes. However, our results remain unchanged if we do not control for the Big Five. 
Table 1: Individual risk attitude and patience of graduates and occupational sorting, standardized regression coefficients (44 occupations)

\begin{tabular}{|c|c|c|c|c|c|}
\hline & Earnings risk & $\begin{array}{l}\text { Mid-career } \\
\text { earnings risk }\end{array}$ & $\begin{array}{l}\text { Cyclical } \\
\text { sensitivity }\end{array}$ & $\begin{array}{l}\text { Unemployment } \\
\text { risk }\end{array}$ & $\begin{array}{l}\text { Earnings } \\
\text { growth }\end{array}$ \\
\hline \multirow[t]{2}{*}{ Career risk attitude } & $0.081^{* * *}$ & $0.072 * * *$ & $0.053^{* * *}$ & $0.040 * * *$ & \\
\hline & $(0.015)$ & $(0.015)$ & $(0.015)$ & $(0.015)$ & \\
\hline \multirow[t]{2}{*}{ Patience } & & & & & 0.011 \\
\hline & & & & & $(0.015)$ \\
\hline Controls & No & No & No & No & No \\
\hline \multirow[t]{2}{*}{ Career risk attitude } & $0.080^{* * *}$ & $0.067 * * *$ & $0.047^{* * *}$ & $0.052^{* * *}$ & \\
\hline & $(0.014)$ & $(0.014)$ & $(0.014)$ & $(0.014)$ & \\
\hline \multirow[t]{2}{*}{ Patience } & & & & & $0.023 * *$ \\
\hline & & & & & $(0.010)$ \\
\hline Controls ${ }^{a)}$ & Yes & Yes & Yes & Yes & Yes \\
\hline $\begin{array}{l}\text { Adjusted } \mathrm{R}^{2} \text { (model } \\
\text { with covariates) }\end{array}$ & 0.193 & 0.205 & 0.215 & 0.160 & 0.532 \\
\hline $\mathrm{N}$ & 4,584 & 4,584 & 4,584 & 4,584 & 4,584 \\
\hline
\end{tabular}
$\mathrm{p}<0.01$

a) Age (linear, squared, and cube), gender, foreign background ( $1^{\text {st }}$ and $2^{\text {nd }}$ generation migrant), education level, $\mathrm{BMI}$, and Big Five.

Table 1 shows that there is a positive relationship between an individual's career risk attitude and the measures of occupational earnings and employment risks: individuals who are more willing to take risks sort into occupations with a higher earnings risk, mid-career earnings risk, cyclical sensitivity and unemployment risk. The findings in Table 1 still hold once we control for several relevant background characteristics. ${ }^{27}$ Note that the association between career risk attitude and the measures of the riskiness of occupations is strongest for occupational earnings risk: a one standard deviation increase in career risk attitude is associated with choosing for an occupation with a 0.08 standard deviation higher earnings risk.

27. The coefficient for general risk attitude in the earnings risk model with covariates is 0.029 (not shown in Table $1)$, and it is significant at the $10 \%$-level. 
The table also shows that there is a positive relation between an individual's patience and earnings growth: individuals who are more patient sort into occupations that are characterized by higher lifetime earnings growth. The standardized regression coefficient when we use the implied annual discount rate instead of patience in the last column of Table 1 equals -0.022 (significant at $10 \%$ ), again suggesting that more patient individuals sort into occupations with steeper earnings profiles. All the results in Table 1 are robust to the exclusion of occupations with fewer than 30 observations.

As argued by Beauchamp et al. (2011) risk attitudes are likely measured with error. If this is the case, our coefficient for career risk attitude is likely to be biased downward. In a sensitivity analysis, we follow Andrabi et al. (2011) and instrument career risk attitude using risk attitude in different fields: general risk attitude and risk attitude in financial matters. For the model (with covariates) in Table 1, for example, the F-test of excluded instruments equals 838.48, and the coefficient of career risk attitude on occupational earnings risk equals 0.094 (significant at 1\%). This approach, however, only accounts for measurement error in a specific item, and not for correlated error across items. We therefore also estimated an error in variable model, where the reliability of risk attitude is set to .6, the test-retest correlation in risk attitude reported by Dohmen et al. (2010) and Beauchamp et al. (2011). In this case, the coefficient of career risk attitude on occupational earnings risk equals 0.144 (significant at $1 \%$ ).

\section{Robustness checks}

In this section, we discuss three potential issues pertaining to our analyses around career risk attitude and patience. Firstly, because schooling and occupational decisions could be taken jointly, we check that our main results are robust to controlling for field of study. Secondly, we check that occupational sorting is not driven by young graduates' knowledge about their abilities in particular occupations rather than their risk attitude. Thirdly, we discuss a potential measurement issue in our measure of the earnings risk, namely that it could reflect compensating earnings differentials that are distinct from the earnings risk we are trying to capture, and that are not well captured by occupational dummies.

\subsection{Field of study}

We motivated our focus on occupational choice from the fact that the variance in earnings within education fields is large (Brunello \& Cappellari, 2008), and the occupation choice set of individuals from 
specific education fields is large (Heijke et al., 2003). In the Dutch labor market, there is for most education fields not a one on one correspondence with a particular occupation. Using the 2009 and 2010 waves of the Dutch Labor Force Survey, Bertrand-Cloodt et al. (2011) calculated the GiniHirschman-index as a measure of concentration of individuals from specific educational background (102 in total) in occupations (127 in total). The index ranges from 1.2 for university graduates with a dentist degree (who almost all are dentist) to $\mathbf{2 7 . 5}$ for graduates from university of applied science with a degree in environment studies (who work in diverse occupations such as environmentalist, managers, commercial employee, etc.) with an average of 10.

Table 2: Individual risk attitude and patience of graduates and occupational sorting when controlling for field of study, standardized regression coefficients (44 occupations)

\begin{tabular}{|c|c|c|c|c|c|}
\hline & Earnings risk & $\begin{array}{l}\text { Mid-career } \\
\text { earnings risk }\end{array}$ & $\begin{array}{l}\text { Cyclical } \\
\text { sensitivity }\end{array}$ & $\begin{array}{l}\text { Unemployment } \\
\text { risk }\end{array}$ & $\begin{array}{l}\text { Earnings } \\
\text { growth }\end{array}$ \\
\hline Career risk attitude & $\begin{array}{l}0.036^{* * *} \\
(0.012)\end{array}$ & $\begin{array}{l}0.029^{* *} \\
(0.012)\end{array}$ & $\begin{array}{l}0.029^{* *} \\
(0.013)\end{array}$ & $\begin{array}{l}0.023^{*} \\
(0.013)\end{array}$ & \\
\hline Patience & & & & & $\begin{array}{l}0.011 \\
(0.009)\end{array}$ \\
\hline Controls ${ }^{a}$ & Yes & Yes & Yes & Yes & Yes \\
\hline Field of study ${ }^{b}$ & Yes & Yes & Yes & Yes & Yes \\
\hline $\begin{array}{l}\text { Adjusted } R^{2} \text { (model } \\
\text { with covariates) }\end{array}$ & 0.448 & 0.409 & 0.309 & 0.270 & 0.612 \\
\hline $\mathrm{N}$ & 4,584 & 4,584 & 4,584 & 4,584 & 4,584 \\
\hline
\end{tabular}

OLS regressions. Standard errors in parentheses. Asterisks indicate significance levels: ${ }^{*} p<0.10^{* *} p<0.05^{* * *}$ $\mathrm{p}<0.01$

a) Age (linear, squared, and cube), gender, foreign background $\left(1^{\text {st }}\right.$ and $2^{\text {nd }}$ generation migrant), education level, $\mathrm{BMI}$, and Big Five.

b) Dummies for economics, technique and engineering, health, agriculture, social sciences, education, law, science, and general studies.

Using our data on graduates, we defined 9 fields of study (economics, technique and engineering, health, agriculture, social sciences, education, law, science, and general studies). We repeat our analyses in Table 1, but control for the field of study in addition to the other covariates. The outcomes of the analyses are reported in Table 2 . The standardized regression coefficients for career risk attitude in 
Table 2 are lower than those in Table 1. However, they still are significant when we control for field of education. This suggests that graduates, to some extent jointly choose a field of study and an occupation, but that graduates career risk attitude still explains the occupational sorting even after we control for level and field of education.

\subsection{Ability}

Our implicit assumption in this paper has been that graduates do not know anything about their own abilities, and henceforth cannot anticipate what their job prospects are or where they will end up in the earnings distribution in a specific occupation. This is contestable since school grades and degrees might contain information about abilities that are valued on the labor market. Conditional on this information, the expected earnings variance that graduates base their choices on might be quite different from the unconditional variance in expected wages. If the position within an occupation's wage distribution is largely determined by a worker's ability, and if individuals knew their position in an occupations ability distribution ${ }^{28}$, much of the uncertainty of future wages or the wage risk of an occupation would disappear. We could expect high ability graduates to sort into occupations with high earnings risk if they expected to end up in the right-hand tail of occupation-specific earnings distributions (i.e. an earnings premium compared to average workers in that occupation) and low ability graduates to sort into occupations with a low earnings risk. If abilities and risk preferences are related, this would bias our findings. However, we do not find evidence that individuals who are more able sort into occupations with higher earnings risk. We considered several indicators of ability, including the level of education, school grade at completion of education, entry level wage and unemployment at labor market entry, which have all been argued to reveal such differences in ability.

First, individuals who completed education with better grades opt, if anything, for occupations with lower earnings risk, conditional on their risk attitudes. This result is indicated by a regression in which we added the school grade obtained upon finishing education as a proxy for cognitive abilities to the specifications of Table $1 .^{29}$ Better grades are positively correlated with sorting into occupations with lower earnings risk and occupations with high earnings growth, but are uncorrelated with employment

28. Chevalier et al. (2009) showed that individuals have limited knowledge about their own position in the distribution of abilities.

29. Poropat (2009) shows that school grades are correlated with intelligence as well as dimensions of personality. In our data, school grades are positively correlated with the gross hourly wage in the current job. 
risk. Importantly, the inclusion of the school grade does not affect the coefficient estimates of the measures for risk attitudes and patience.

Second, although we control for educational level to proxy abilities, we re-estimated the models in Table 1 for groups of graduates with a similar education level. This makes the groups more homogenous in terms of abilities. For high educated individuals (college and university graduates, i.e. ISCED 5A or ISCED 5B), we find virtually the same results as those reported in Table 1. For less educated individuals with a degree that does not exceed secondary education, the results point in the same direction, but the coefficients are not significant. However, graduates at lower levels of education face a different choice set. They can choose to either enter the labor market or continue education, but our analyses only include labor market entrants. ${ }^{30}$

Third, we regress the gross hourly wage of graduates in their current job on the set of covariates used in Table 1. The residuals from that regression reflect differences in earnings' graduates that cannot be explained by standard human capital characteristics that could be due to differences in unobserved abilities. We included the residuals as an additional covariate in the analyses in Table 1. However, this does not change any of our results. Finally, we also checked that experience of unemployment between leaving school and $1^{\text {st }}$ job (this could reveal a precarious entry that affects graduates' subsequent choices on the labor market or wait unemployment) does not affect our results, and it doesn't.

\subsection{Do residuals reflect compensating earnings differentials?}

Our measure of earnings risk is based on the residuals from the Mincer earnings regression. This earnings regression was estimated with the inclusion of occupational dummies. However, occupations within the 44 groups of occupations could differ in many respects. For example, heterogeneity in job

30. Selective labor market entry could generate a positive correlation between risk attitudes and occupational earnings risk if earnings risk differed by education level and if graduates selected into education based on their risk preferences but were myopic so as not to consider occupational earnings risk when choosing an occupation. However, we do not find that risk attitudes are related to the decision to continue education. For example, risk attitudes do not affect the decision to continue education in a sample of more than 4,400 young individuals from our 2008 survey who graduated with an intermediate vocational degree (Dutch MBO). About half of them enter college and half of them enter the labor market. Moreover, occupational earnings risk does not vary much at different educational levels, except for individuals who completed higher education. They do face higher earnings risk. If we condition on having completed higher education and limit our sample to college and university graduates, our results become even stronger than those reported in Table 1. 
characteristics and job disamenities across occupations within our groups of occupations could result in compensating wage differentials that are not captured by the occupational dummies. In this case, the unexplained variance in earnings across occupations would not only reflect differences in earnings risk. ${ }^{31}$ We account for this in two ways.

Firstly, using the administrative earnings data from Statistics Netherlands matched to the Dutch Labor Force Survey, we re-estimated the occupational earnings and mid-career earnings risk using a more detailed coding that allows us to distinguish among 127 types of occupation. ${ }^{32}$ The idea is that when using a more detailed classification, jobs are more homogeneous in their characteristics. We match the earning risk to the graduates' occupation and estimate the specification for the earnings risk and midcareer earnings risk from Table 1 for these 127 occupations. The results reported in Table 3 coincide largely with those in Table $1 .^{33}$ This indicates that the results are independent of the level of aggregation used for the occupational group.

Table 3: Individual risk attitude and patience of graduates and occupational sorting, standardized regression coefficients (127 occupations)

\begin{tabular}{lll}
\hline & Earnings risk & Mid-career earnings risk \\
\hline Career risk attitude & $0.081^{* * *}$ & $0.075^{* * *}$ \\
& $(0.014)$ & $(0.014)$ \\
Controls $^{\mathrm{a})}$ & Yes & Yes \\
\hline Adjusted $\mathrm{R}^{2}$ & 0.147 & 0.159 \\
$\mathrm{~N}$ & 4,584 & 4,584 \\
\hline OLS regressions. Standard errors in parentheses. Asterisks indicate significance levels: ${ }^{*} p<0.10^{* *} p<0.05^{* * *}$ \\
$\mathrm{p}<0.01$ \\
a) Age (linear, squared, and cube), gender, foreign background $\left(1^{\text {st }}\right.$ and $2^{\text {nd }}$ generation migrant), education level, \\
BMI, and Big Five.
\end{tabular}

31. This issue, of course, would not affect our findings with respect to the employment risk or the earnings growth.

32. This is equivalent to the level of detail in the ISCO 3 digit occupational classification.

33. The results in Table 3 still hold when we exclude small occupations with fewer than 30 observations. We also checked whether the other results reported in Table 1 still hold when we use a more detailed occupational coding. The coefficient of career risk attitude in the cyclical sensitivity model is unchanged, but it is lower and less significant in the unemployment risk model. The coefficient of patience in the earnings growth model is no longer significant. 
Secondly, we use a different dataset - the Dutch Labor Supply Panel (the data we used to calculate our measure of occupational unemployment risk) - that allows us to explicitly control for job characteristics and job disamenities that could result in compensating wage differentials within occupations. We do this because there could still be a large amount of heterogeneity in job traits, even within the more detailed 127 occupational groups. This data contains a rich set of job characteristics that we use to estimate an augmented Mincer earnings regression. Using the 2008 wave of the Dutch Labor Supply Panel, we estimate an earnings function that controls for gender, age (linear and squared), tenure (linear and squared), education, and 127 occupation dummies. In addition, we estimate the same model, but including dummy variables for 17 potential disamenities of the job (such as physically heavy work, mentally heavy work, working with dangerous products, repetitive tasks, working in cold/hot temperatures, irregular working times, shift work). As before, we calculate the earnings risk as the standard deviation of the residuals form the earnings regression for each of the 127 occupations. ${ }^{34}$ To the extent that residuals reflect compensating wage differentials for different types of occupations within the 127 groups, the estimates from the second model are potentially better because the job characteristics dummies will pick up such differences. Because the Dutch Labor Supply Panel also includes the general risk question, this allows us to test whether the relationship between risk attitude and occupational sorting discussed in Table 1 is robust to further controls for job disamenities. Comparing the results in Table 4 to those in Table 1 shows that our results are indeed robust: ${ }^{35}$ the results for the model that measures earnings risk with the inclusion of extensive controls for job characteristics are the same as for the model that does not have these controls. We conclude that the relationships we estimate are not driven by compensating wage differentials across occupations.

34. Because of the limited size of the data, we refrain from calculating the mid-career earnings risk.

35. Risk attitude is here measured with the general risk question. The estimates in Table 4 are based on a sample of adults aged 20 to 59, which is a different sample than a sample of graduates. The control variables in the model are somewhat different from those in Table 1 because the data does not include information on $1^{\text {st }}$ and $2^{\text {nd }}$ generation migrants, nor variables to measure the Big Five. We also control for tenure. Like in Table 1 and 2 , all variables are standardized. 
Table 4: Regression of the earnings risk on general risk attitude, model with and without controls for job disamenities, standardized regression coefficients

\begin{tabular}{lll}
\hline & \multicolumn{2}{c}{ Earnings risk of occupation } \\
\cline { 2 - 3 } & Calculated from wage regression & Calculated from wage regression \\
& without control for job disamenities & with control for job disamenities \\
\hline General risk attitude & $0.046^{* *}$ & $0.047^{* * *}$ \\
& $(0.018)$ & $(0.018)$ \\
Controls $^{\mathrm{a})}$ & Yes & Yes \\
\hline Adjusted-R & 0.014 & 0.017 \\
$\mathrm{~N}$ & 3,407 & 3,407 \\
\hline
\end{tabular}

OLS regressions. Standard errors in parentheses. Asterisks indicate significance levels: ${ }^{*} p<0.10^{* *} p<0.05^{* * *}$ $p<0.01$.

a) Age (linear, squared, cube), tenure (linear, squared), gender, foreign born, education level.

\section{Preferences and occupational mobility}

For young labor market entrants the sorting process might not be completed in the first few years of their career, as they might accept second-best jobs or chose to work in occupations to avoid unemployment (Ryan, 2001) or to increase later career chances (Jovanovic \& Nyarko, 1997). If economic preferences are crucial determinants of preferred occupations, we expect that individuals who are 'badly' matched to an occupation given their preferences are more likely to change job. ${ }^{36}$ We cannot test this with our survey among graduates. To investigate this, we match the earnings risk as measured using the administrative earnings data from Statistics Netherlands to the 2006 and 2008 respondents of the Dutch Labor Supply Panel for the 44 occupations. ${ }^{37}$ Using information on risk attitude measured for these same individuals in the 2008 wave of the panel, we define a match to be 'bad' when the individual has above (below) median risk attitude (using the general risk question) but is employed in an occupation in 2006 with below (above) median earnings risk. 13\% of the Dutch adults appear to be badly sorted. Occupational mobility is defined as a change of occupation between 2006 and 2008. On a yearly basis, about a quarter of all employed individuals switch occupation in our 44 occupation classification.

36. This 'bad' sorting could be the result of a wrong choice of the school leaver based on insufficient information about an occupation's characteristics, or the unavailability of suitable occupations around the time of initial job search.

37. We merge the information using 44 occupational codes. 
Using a Probit model, we estimate the probability of experiencing a change of occupation, conditional on the quality of the match.

Table 5: Probit results for occupational mobility (44 occupations) between 2006 and 2008 given quality of match, marginal effects

\begin{tabular}{|c|c|c|c|c|}
\hline & $\begin{array}{l}\text { Change to other } \\
\text { occupation }\end{array}$ & $\begin{array}{l}\text { Change to other } \\
\text { occupation }\end{array}$ & $\begin{array}{l}\text { Change to more } \\
\text { risky occupation }\end{array}$ & $\begin{array}{l}\text { Change to less } \\
\text { risky occupation }\end{array}$ \\
\hline \multirow[t]{2}{*}{ Wrong match (general risk attitude) } & $0.048^{* *}$ & $0.047^{* *}$ & & \\
\hline & $(0.021)$ & $(0.053)$ & & \\
\hline
\end{tabular}

High risk attitude, but sorted in

occupation with low earnings risk

$0.142 * * *$

(0.023)

Low risk attitude, but sorted in

occupation with high earnings risk

$0.118^{* * *}$

(0.020)

\begin{tabular}{lllll} 
Controls $^{\mathrm{a})}$ & No & Yes & Yes & Yes \\
\hline Pseudo-R-squared & 0.002 & 0.022 & 0.022 & 0.021 \\
$\mathrm{~N}$ & 2,323 & 2,315 & 2,300 & 2,300
\end{tabular}

a) Age (linear, squared, cube), tenure (linear, squared), gender, foreign born, education level.

Standard errors in parentheses

$* p<0.10, * * p<0.05, * * * p<0.01$

The results in Table 5 show that individuals who - given their risk attitude - are badly matched, are about 5 percentage points more likely to change job than individuals who are properly matched to their job. This result is robust to the inclusion of a set of control variables. In addition, the table shows that individuals with above-median risk attitude who are sorted in jobs with below-median earnings risk are $14 \%$ more likely to switch to more risky occupations. Likewise, individuals with below-median risk attitude who are sorted in jobs with above-median earnings risk are $12 \%$ more likely to switch to less risky occupations. This suggests that job mobility, in parts, only corrects for inefficiencies in sorting in the job match. 


\section{Concluding remarks}

We have shown that risk attitudes and patience of young graduates from high-school, college and university are systematically correlated with the riskiness and timing of income streams of occupations. Using a large administrative data set representative of the whole working population, we characterize occupations in terms of earnings risk, employment risk and earnings growth path.

Young graduates who are more willing to take risks are more likely to choose occupations with higher earnings risk, a high mid-career earnings risk, and a high employment risk. Young graduates who are patient are significantly more likely to choose for occupations with steep earnings profiles. These results are robust to changes in our model specification. Occupational mobility patterns are in line with our findings on the role of economic preferences in occupational sorting. Individuals who are not working in occupations that are in line with their economic preferences are shown to be more likely to switch towards a job that better fits their economic preferences.

A causal interpretation of these sorting patterns hinges on the assumption that the correlation between economic preferences is not entirely driven by exposure effects. Reverse causality, i.e., that occupation characteristics shape preferences, is an unlikely explanation for our results. First, we have designed our study such that preferences are measured around the time that young graduates make their occupation choices. Hence there is little scope for exposure to characteristics of occupations in which they work to shape preferences. Second, there is evidence that risk attitudes are stable, and if anything change only very gradually over time (Sahm, 2012; Borghans et al., 2008). We showed that this also holds for young graduates at the time of labor market entry. Because of this, we take our findings as suggestive evidence for a causal relationship between economic preferences and occupation's earnings profiles.

The results lead to two implications. First, better information on occupational earnings risk and earnings profiles fosters efficient allocation on the labor market. Graduates deliberately sort themselves into occupations with characteristics that are in line with their economic preferences. Having good information about these characteristics should improve the career choices of graduates. Second, rapid changes in occupational characteristics, affecting occupational earnings risks or the earnings profiles, will lead to different composition in worker types. It will also lead to reduced job satisfaction among incumbent worker who sorted into the occupation while different characteristics were still valid. 


\section{References}

Almlund, M., Duckworth, A. L., Heckman, J. J., Kautz, T. D. (2011). Personality psychology and economics (No. w16822). National Bureau of Economic Research.

Andrabi, T., Das, J., Khwaja, A., Zajonc, T., 2011. Do value-added estimates add value? Accounting for learning dynamics. American Economic Journal: Applied Economics 3(3), 29-54.

Antecol, H., Cobb-Clark, D., 2013. Do non-cognitive skills help explain the occupational segregation of young people? Labour Economics, 2013, 21, 59 - 73.

Arcidiacono, P., 2004. Ability sorting and returns to college major. Journal of Econometrics 121(1-2), 343-375.

Arcidiacono, P., Hotz, J., Kanga, S., 2012. Modeling college major choices using elicited measures of expectations and counterfactuals. Journal of Econometrics 166(1), 3-16

Beauchamp, J., Cesarini, D., Johannesson, M., 2011. The psychometric properties of measures of economic risk preferences. Available on request from https://files.nyu.edu/dac12/public/.

Bertrand-Cloodt, D., Cörvers, F., Dohmen, T., Dupuy, A., Fouarge, D., Grip, A. de, Kriechel, B., Nelen, A., Thor, J. van, 2011. De arbeidsmarkt naar opleiding en beroep tot 2016. Maastricht: ROA-R-2011/8.

Betts, J., 1996. What do students know abour wages? Evidence from a survey of undergraduates. The Journal of Human Resources 31(1), 27-56.

Bonin, H., Dohmen, T., Falk, A., Huffman, D., Sunde, U., 2007. Cross-sectional earnings risk and occupational sorting: the role of risk attitudes. Labour Economics 14(6), 926-937.

Borghans, L., Golsteyn, B., 2006. Time discounting and the body mass index. Evidence from the Netherlands. Economics and Human Biology 4(1), 39-61.

Borghans, L., Duckworth, A., Heckman, J., Ter Weel, B., 2008. The economics and psychology of personality traits. Journal of Human Resources 43(4), 972-1059.

Budria, S., Diaz-Serrano, L., Ferrer-i-Carbonell, A., Hartog, J., 2012. Risk attitude and wage growth: replicating Shaw (1996). Empirical Economics (forthcoming).

Brunello, G., Cappellari, L., 2008. The labour market effects of AlmaMater: Evidence from Italy. Economics of Education Review 27(5), 564-574.

Caner, A., Okten, C., 2010. Risk and career choice: evidence from Turkey. Economics of Education Review 29(6), 1060-1075. 
Caliendo, M., Cobb-Clark, D., Uhlendorff, A., 2010. Locus of control and job search strategies. IZA DP No. 4750, IZA, Bonn.

Chevalier, A., Gibbons, S., Thorpe, A., Snell, M., Hoskins, S., 2009. Students' academic self-perception. Economics of Education Review 28(6), 716-727.

Cörvers, F., Dupuy, A., Dijksman, S. , Kriechel, B., Montizaan, R., 2008. Methodiek arbeidsmarktprognoses en -indicatoren 2007-2012. TR-2008/2, ROA, Maastricht.

Cramer, J., Hartog, J., Jonker, N., Van Praag, C., 2002. Low risk aversion encourages the choice for entrepreneurship: an empirical test of a truism. Journal of Economic Behavior \& Organization 48(1), 29-36.

DeLeire, T., Levy, H., 2004. Worker sorting and the risk of death on the job. Journal of Labor Economics 22(4), 925-953.

De Paola, M., Gioia, F., 2012. Risk aversion and major choice: evidence from Italian students. Università della Calabria, Working Paper 7-2011.

Dohmen, T., Falk, A., Huffman, D., Sunde, U., Schupp, J., Wagner, G., 2010. The measurement and stability of risk attitudes. Mimeo, Maastricht University.

Dohmen, T., Falk, A., Huffman, D., Sunde, U., Schupp, J., Wagner, G., 2011. Individual risk attitudes: measurement, determinants and behavioral consequences. Journal of the European Economic Association 9(3), 522-550.

Ekelund, J., Johansson, E., Järvelin, M-R., Lichtermann, D., 2005. Self-employment and risk aversionevidence from psychological test data. Labour Economics 12(5), 649-659.

Frederick, S., Loewenstein, F., O'Donoghue, T., 2002. Time Discounting and Time Preference: A Critical Review. Journal of Economic Literature 40(2), 351-401.

Fouarge, D., Kriechel, B., Dohmen, T., 2012. Risicoattitude en beroepskeuze van schoolverlaters, Tijdschrift voor Arbeidsvraagstukken 28(2), 207-223.

Gerlitz, J.-Y., Schupp, J., 2005. Zur Erhebung der Big-Five-basierten Persönlichkeitsmerkmale im SOEP. DIW Research Notes 4, DIW, Berlin.

Guiso, L., Paiella, M., 2005. The role of risk aversion in predicting individual behavior. Bank of Italy Working Paper 546.

Han, E., Norton, E. C., Powell, L. M. (2011). Direct and indirect effects of body weight on adult wages. Economics \& Human Biology, 9(4), 381-392.

Hartog, J., 2011. A risk augmented mincer earnings equation? Taking stock. In: Polachek, S., Tatsiramos, K. (Eds.). Research in Labor Economics (33), Emerald Group Publishing Limited, 129-173. 
Hartog, J., Plug, E., Diaz-Serrano, L., Vieira, J., 2003. Risk compensation in wages - A replication. Empirical Economics 28(3), 639-647.

Heckman, J., Stixrud, J., Urzua. S., 2006. The effects of cognitive and noncognitive abilities on labor market outcomes and social behavior. Journal of Labor Economics 24(3), 411-482.

Heijke, H., Matheeuwsen, A., Willems, E., 2003. Clustering educational categories in a heterogeneous labour market. Education Economics 11(1), 89-108.

Isphording, I., 2010. Risky business - The role of individual risk attitudes in occupational choice. RUHR Economic Papers No 187.

Jovanovic, B., Nyarko, Y., 1997. Stepping-stone mobility. Carnegie-Rochester Conference Series on Public Policy 46(1), 289-325

King, A., 1974. Occupational choice, risk aversion and wealth. Industrial and Labor Relations Review 27(4), 586-596.

Le, A., Miller, P., W. Slutske, Martin, N., 2010. Attitudes towards economic risk and the gender pay gap. IZA DP No. 5393, IZA, Bonn.

McGoldrick, K., 1995. Do women receive compensating wages for earnings uncertainty? Southern Economic Journal 62(1), 210-222.

Meier, S., Sprenger, C., 2010. Stability of time preferences. IZA DP No. 4756, IZA, Bonn.

Munasinghe, L., Sicherman, N., 2006. Why do dancers smoke? Smoking, time preference, and wage dynamics. Eastern Economic Journal 32(4), 595-616.

Murphy, K., Topel, R., 1987. Unemployment, risk and earnings: Testing for equalizing differences in the labor market. In: Lang, K., Leonard, J. (Eds.), Unemployment and the Structure of Labor Markets. New York: Basil Blackwell, pp. 103-140.

Peters, E., Vastfjall, D., Slovic, P., Mertz, C., Mazzocco, K., Dickert, S., 2006. Numeracy and decision making. Psychological Science 17(5), 407-413.

Phillips, S., Jome, L., 2005. Vocational choices: What do we know? What do we need to know?. In: Walsh, W., Savickas, M. (Eds.). Handbook of Vocational Psychology (3rd ed.). Mahwah, NJ: Erlbaum, 127-154.

Pollmann, D., Dohmen, T., Palm, F.C., 2012. Robust Estimation of Wage Dispersion with Censored Data: An Application to Occupational Earnings Risk and Risk Attitudes. IZA Discussion Paper 6447.

Poropat, A., 2009. A meta-analysis of the five-factor model of personality and academic performance. Psychological Bulletin 135(2), 322-338.

Pratt, J., 1964. Risk aversion in the small and in the large. Econometrica 31(1-2), 122-136. 
Ryan, P., 2001. The school-to-work transition: a cross-national perspective. Journal of Economic Literature 39(1), 34-92.

Sahm, C., 2012. How much does risk tolerance change? Quarterly Journal of Finance 2(4).

Saks, R., Shore, S., 2005. Risk and career choice. Advances in Economic Analysis and Policy 5(1), Article 7, 1-43.

Schweri, J., Hartog, J., Wolter, S., 2011. Do students expect compensation for wage risk? Economics of Education Review 30(2), 215-227.

Shaw, K., 1996. An empirical analysis of risk aversion and income growth. Journal of Labor Economics 14(4), 626-653.

Stark, A., 2007. Which fields pay, which fields don't? An examination of the returns to university education in Canada by detailed field of study. Economic Analysis and Policy Division, Department of Finance, Canada.

Strathman, A., Gleicher, F., Boninger, D., Edwards, C., 1994. The consideration of future consequences: Weighing immediate and distant outcomes of behavior. Journal of Personality and Social Psychology 66(4), 742-752.

Sutter, M., Kocher, M., Glatzle-Rützler, D., Trautmann, S., 2013. Impatience and uncertainty: experimental decisions predict adolescents' field behavior. American Economic Review 103(1), 510531.

Vischer, T., Dohmen, T., Falk, A., Huffman, D., Schupp, J., Sunde, U., Wagner, G., 2013. Validating an Ultra Short Survey Measure of Patience. Economics Letters 120(2), 142-145

Webbink, D., Hartog, J., 2004. Can students predict starting salaries? Yes! Economics of Education Review 23(2), 103-113.

Weber, E., 2001. Personality and risk taking. In: Smelser, N., Baltes, P. (Eds.). International Encyclopedia of the Social and Behavioral Sciences. Oxford, UK: Elsevier, pp. 11274-11276.

Webley, P., Nyhus, E., 2006. Parents' influence on children's future orientation and saving. Journal of Economic Psychology 27(1), 140-164.

Weiss, R., 1970. The effect of education on the earnings of blacks and whites. Review of Economics and Statistics 52(2), 150-159. 
Appendix A: Sample statistics

Table A.1: Sample statistics

\begin{tabular}{|c|c|c|c|c|c|}
\hline & $\mathrm{N}$ & Mean & Std dev & Min & Max \\
\hline General risk attitude & 4,584 & 6.166 & 1.963 & 0.000 & 10.000 \\
\hline Career risk attitude & 4,584 & 6.099 & 1.945 & 0.000 & 10.000 \\
\hline Patience & 4,584 & 3.432 & 1.493 & 1.000 & 7.000 \\
\hline Implied annual discount rate & 3,963 & 43.197 & 44.376 & 0.000 & 250.000 \\
\hline Hourly wage (log) & 4,584 & 2.932 & 0.270 & 2.472 & 3.435 \\
\hline Earnings risk & 4,584 & 0.282 & 0.048 & 0.191 & 0.492 \\
\hline Mid-career earnings risk & 4,584 & 0.281 & 0.061 & 0.194 & 0.548 \\
\hline Cyclical sensitivity & 4,584 & 0.948 & 0.391 & 0.280 & 2.730 \\
\hline Unemployment probability & 4,584 & 2.787 & 1.190 & 0.000 & 8.953 \\
\hline Wage growth (age 25 - age 45 ) & 4,584 & 0.339 & 0.132 & 0.126 & 0.651 \\
\hline Female & 4,584 & 0.623 & 0.485 & 0.000 & 1.000 \\
\hline Age & 4,584 & 23.439 & 3.442 & 16.000 & 35.000 \\
\hline ISCED 2 or less & 4,584 & 0.080 & 0.271 & 0.000 & 1.000 \\
\hline $\begin{array}{l}\text { ISCED } 3 \text { non-vocational track } \\
\text { ISCED } 3 \text { vocational school-based }\end{array}$ & 4,584 & 0.084 & 0.277 & 0.000 & 1.000 \\
\hline track & 4,584 & 0.142 & 0.349 & 0.000 & 1.000 \\
\hline $\begin{array}{l}\text { ISCED } 3 \text { vocational practical- } \\
\text { based track }\end{array}$ & 4,584 & 0.044 & 0.205 & 0.000 & 1.000 \\
\hline ISCED 5B & 4,584 & 0.458 & 0.498 & 0.000 & 1.000 \\
\hline ISCED 5A & 4,584 & 0.192 & 0.394 & 0.000 & 1.000 \\
\hline Foreigner (1st generation) & 4,584 & 0.040 & 0.196 & 0.000 & 1.000 \\
\hline Foreigner (2nd generation) & 4,584 & 0.069 & 0.254 & 0.000 & 1.000 \\
\hline Body Mass Index & 4,584 & 23.024 & 3.237 & 13.581 & 41.623 \\
\hline Openness & 4,584 & 0.000 & 1.000 & -3.649 & 2.244 \\
\hline Conscientiousness & 4,584 & 0.000 & 1.000 & -4.233 & 4.272 \\
\hline Extraversion & 4,584 & 0.000 & 1.000 & -3.697 & 4.343 \\
\hline Agreeableness & 4,584 & 0.000 & 1.000 & -4.616 & 4.966 \\
\hline Neuroticism & 4,584 & 0.000 & 1.000 & -3.263 & 4.164 \\
\hline
\end{tabular}




\section{Appendix B: Indicator of Cyclical Sensitivity}

The indicator of cyclical sensitivity is determined over a period of 20 years, using the Labor Force Surveys from 1987-2008. It determines the occupation and sector specific reaction of changes in the workforce. It is computed for 127 occupational groups (for our analyses on 44 occupations, we use the weighted average of the indicator of 127 occupations). We use the occupation specific indicator that captures the sensitivity by sector, weighted by the importance of the sector for the occupation and the fluctuation of the occupation within a sector. The indicator is determined as follows (Cörvers et al., 2008):

$C S_{o t}=\sum_{s} \frac{E_{o s t}}{E_{s t}} \alpha_{o s t} C S_{s t}$

$C S_{o t}=$ cyclical sensitivity of occupation $o$ at time $t$

$E_{\text {ost }}=$ number of persons employed in occupation $o$ in sector $s$ at time $t$

$E_{s t}=$ number of persons employed in sector $s$ at time $t$

$\alpha_{o s}=$ extent to which employment in occupation varies with changes in employment in sector $s$

$C S_{s t}=$ sectoral cyclical sensitivity

Where

$$
\begin{aligned}
& C S_{s t}=100 * \sum_{t} \frac{\left|E_{s t}-\bar{E}_{s t}\right|}{E_{s t}} \\
& \bar{E}_{s t}=\frac{E_{s t-1}-E_{s t+1}}{2}
\end{aligned}
$$

$C_{\text {st }}$ is estimated on Labor Force Survey data from 1987-2008

$C S_{o t}$ is estimated on Labor Force Survey data from 1996-2008 


\section{Appendix C: Additional figures}

Figure C.1: Career risk attitude and occupational mean earnings

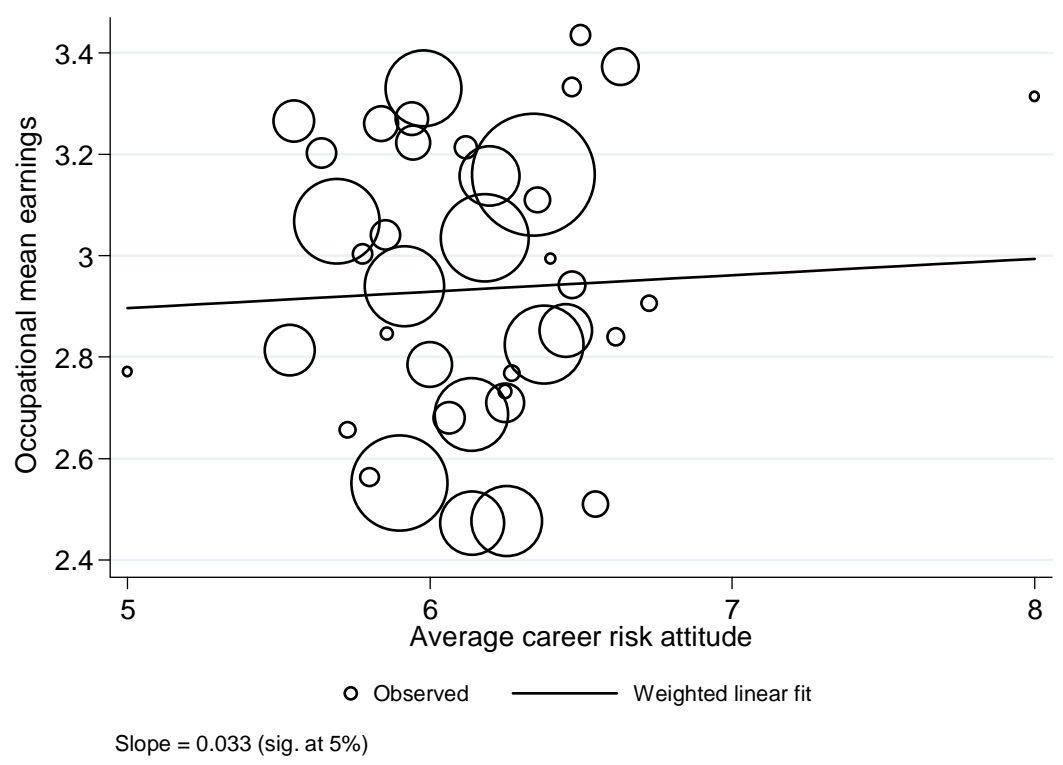

Figure C.2: General risk attitude and occupational earnings risk

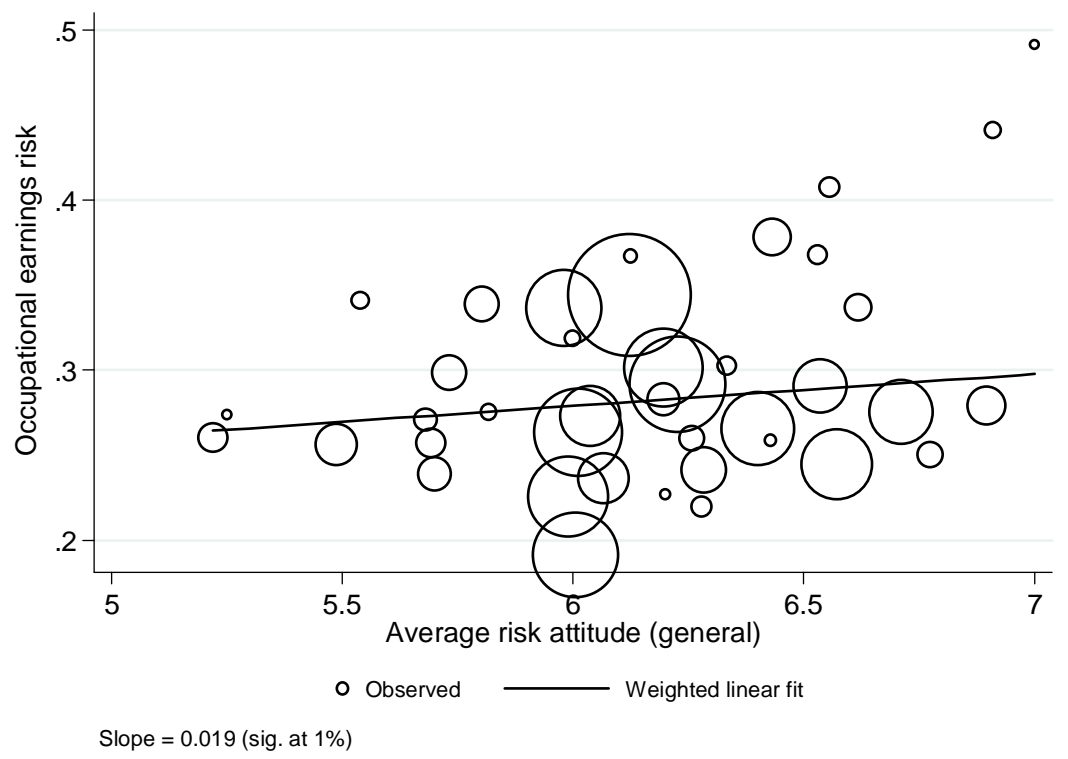


Figure C.3: Implied annual discount rate of graduates and occupational earnings growth

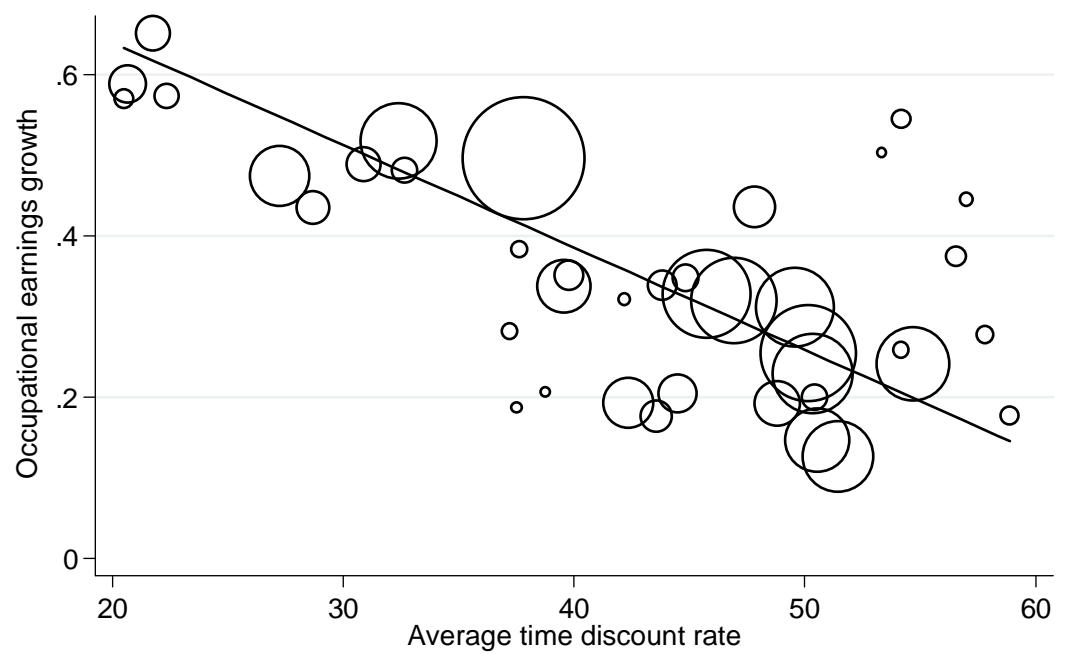

○ Observed Weighted linear fit

Slope $=-0.013$ (sig. at $1 \%)$ 